\title{
CATEGORIES OF THE SELF.
}

In a former paper, ${ }^{1}$ I suggested that, of the two distinct uses or meanings now indicated indifferently by the terms ego and self, the term ego be restricted to one, viz.: the individual who is or may be self-conscious, who can think in terms of ' $I$ '; and that the term self be applied to the other meaning, viz.: that content of consciousness in which an individual recognizes himself. Using the term self in this narrower sense, in this paper I would distinguish and name some six distinct 'selves,' $i$. e., distinct contents, in each of which the conscious individual recognizes himself.

Among other writers James, Baldwin, Stout and Bradley bave enumerated each two or more such ' selves.' In the case of James and Stout their accounts suggest in their form of expression a completeness which I think they do not possess. Indeed it seems to me no writer has approached adequacy in this matter, none has done justice to the complexity of our conception of self, or defined with sufficient care the several 'selves,' or properly emphasized the gulf that lies between one self and another.

The problems of the self and the not-self are now less prominent than they have been. Their importance to metaphysics, however, and particularly to ethics is permanent. It is the ethical significance of ' self' that I have most in mind; and partly for that reason I approach the matter from the side of self-feeling. I hope, too, thereby to make my statements concrete and more readily verifiable.

A few words with regard to the nature of self-feeling, Dewey" says : "Feeling is always a feeling of self; of the hinderance or further" ance of self-development, ${ }^{3}$ through activity." We need, however, the word self-feeling to distinguish those feelings which have for their object self in antithesis to the not-self. James uses the term self-feeling in this latter sense. Such feelings are: pride, humility, shame, self-love, self-pity, etc. The sefeelings are not 'aroused by' self, as James says, but rather, as Hume maintains, are aroused by certain things or qualities which, through instinct or habit, direct those feel-

${ }^{1}$ THE PSYChologtcal BULLEXIN, Sept. 15, 1906.

${ }^{2}$ Psychology, p. 28r.

'The reflexive pronoun self, in such words as self-development, of course need not refer to the self as I have defined that substantive. 
ings toward self. Through such instructive or habitual direction of feelings on the one hand the several contents of self are built up; on the other hand those contents of self reciprocally modify self-feeling.

Of the self feelings I select the general class of self-appreciation. Hume ${ }^{\prime}$ describes pride and humility as simple and uniform impressions, and he uses pride, apparently, in the general sense of self-appreciation. I would show that for each of the 'selves' I now proceed to describe, self-appreciation takes a different form. These forms, are, I think, easily recognizable, and aid us to realize the distinctions between the several selves.

It is often said, and said with great assurance, that, in pride, our own excellence counts for nothing unless we excell others. The statement is, I think, true only for pride that has for its object the self which I shall call the historical self. The historical self is an agent working in a world of agents; it is I as others may know me, as I see myself in a mirror, the living body, speaking, thinking, acting on others, feeling and responding in its own way to the acts of others. Were we to ask the average American what he means by himself, he would probably reply, in effect, that it is this living, active body, which remembers, wills, forecasts; whom others see (though not of course as self), love, honor, fear, despise; which triumphs over others and submits to them. Appreciation of this self means little, if anything, except in terms of comparison with the others, the not-self. Better here means better than others. The emotion of self-appreciation or pride, where this self is concerned, is, it seems to me, always properly called vanity.

But a man may recognize and appreciate himself as an activity pouring forth ' in ready and abundant measure, beating down all resistance, and making use of obstacles only to overcome them.' Such self-appreciation Job ascribes to the horse: "He paweth in the valley, and rejoiceth in his strength. He mocketh at fear. He swalloweth the ground in fierceness and rage; neither believeth he that it is the sound of the trumpet." This feeling of our superior energy we may call exaltation or glory. This self is the inner activity of apperception ( $W$ undt), the sense of inner adjustment (James), in antithesis to the world of means and of obstacles through which and against which my energy, activity or will is or is not realized. I call it the will-self. Self-appreciation here means superiority or inferiority of self to the not-self, but the not-self is not other people. Exaltation

1 Treatise, Bk. II., Part $\mathbf{1}$, Sec. 2.

${ }^{2}$ Dewey, Psychology, p. 265. 
does not require comparison with other people. It may arise through a sense of the superiority of self to a certain mathematical problem, due to my successful solution of it. If, however, I do compare my success with that of. others, I find that the will-self no longer occupies the field; now the self is the historical self, of which the will is regarded as a possession, an inner energy, finding its expression in my acts. The emotion is no longer exaltation but vanity, when I attribute superiority to the will I (the historical self) possess.

By considering another phase of self-appreciation we may discover two other 'selves.' James' says that our self-feeling 'depends entirely on what we $b a c k$ ourselves to be and do,' 'on the ratio of our actualities to our supposed potentialities.' Self-esteem, he maintains, varies directly as our success and inversely as our pretensions. But is this always true? If in 'good faith' one gives up all pretensions to be a gentleman or a philosopher, or whatever it is that one has striven and partly failed to be or do, is one's self-esteem increased? Yes and no! It depends on what 'self' one has in mind. There is an 'ideal' or 'pretension' self, and also a 'realization' self. If I think in terms of the former I identify myself with what I stand for, with my ideals and pretensions, and all the opposing ideals, the pretensions I reject or abandon, are the not-self, I cannot recognize myself in them. There is a self-esteem which regards simply the ideals, not the success, we may well call it, I think, self-respect. James cites the Stoic as one whose self-esteem rises through abandoning pretensions that could not be assured of success. This is but one side of the shield. The Stoic's great self-respect rested not on his success in his few pretensions, but in his acceptance of pretensions which to the Stoic himself seemed to link man with God through a common nature. Christian renunciation is surely not so much what James would have it, a renunciation of ideals, but far more it is the rejection of the whole self of success, of works, of 'claims of wages,' and the adoption of the self of ideals, of infinite ideals, through which the highest self-respect is attained. For this self of pretensions self-esteem varies directly, not inversely as the pretensions.

If I do adopt, however, the category of the realization self, and identify myself, as I may, with so much of my ideals as I have achieved, then forthwith ideals are to me mere ideals, not actual, and not the self. Self is actual. And here James's equation seems to be true. This form of self-appreciation, which I would call exultation or self-satisfaction, varies inversely as my pretensions, for self is

1 Principles of Psychology, Vol. I., p. 310. 
measured by its approach to those pretensions. The true opposite of exultation is the emotion of hunility.

In terms of self-respect and of the ideal self the young Christian knight, for example, was the proudest of men. In terms of exultation, or self-satisfaction, and of the realization self he might well be most humble.

It seems to me we get an important basis, in terms of these categories of self, for distinguishing self-respect and the emotion of humility from less desirable forms of self-appreciation. Those who think, as Hume did, that pride is a 'uniform' impression, describe self-respect and humility as certain degrees of pride. Clearly this is not true. A man who has the greatest self-respect is likely to be most humble. Humility, as an emotion, is a function of the realization self and is the opposite of exultation.

These four 'selves' are those with which self-appreciation is most commonly connected. A fifth category of self is the bodily self. If a woman is proud of her beauty or a man of his strength, commonly the emotion has reference to the efficiency of the beauty or the strength in acting on or influencing other agents. The self-appreciated here is the historical, and the emotion is vanity. On the other hand the bodily self is learned probably without the medium of social relations, chiefly through pains, and through touch and temperature, and through its continual presence. It is passive, receptive; it is fed, warmed, pained; it grows, is sick. The not-self is that world whose pains are not ours, and the presence of any one part of which is not necessary. If self-appreciation is felt for this self it is perhaps delight in the sense of its warmth and sensuous life contrasted with the inertness of the not-self, the world I cannot directly feel. Probably this selfdelight is, as a rule, morbid, except in the very young.

In such a double monster as Helen-Judith, ${ }^{5}$ having common circulation, but a separate nervous system, and of course separate worlds of experience, the pair necessarily acts in unison, for the most part. Hence for most purposes the historical self, for either ego, would tend to include the other as part of the single agent. But the bodily self, for each ego, would be sharply limited by the fact that, beyond a certain point of the skin, touch, temperature and pain stimulations did not affect her, but the other, who was thus, in this connection, part of the not-self. In us the historical self tends to include our clothes; the bodily self is set over against the clothes which warm and chafe it. This difference of limits, however, should merely guide us in realiz-

${ }^{1}$ Ribot, Diseases of Personality, Chap. I., 83. 
ing the difference in meaning between these two categories of self, the bodily and the historical.

A sixth category of the self is the experience self. Stout calls this the inner self; James calls it the me, and the 'empirical ego.' $\mathrm{He}$ would place the bodily, social and spiritual selves within this me, as its constituents; whereas Stout calls the body the outer self, in antithesis to experience, the inner self. It seems to me the experience self is not inner; for what is it inside? The body which it experiences?

The experience self is my experience of objects in antithesis to the objects themselves; it has an order and connection which is not that of the objects. In this connection, my body is part of the not-self, the ' recognition which I get from my mates' is part of the not-self, and even the 'Self of Selves,' what James makes the core of our spiritual life, viz: " the collection of these peculiar motions in the head or between the head and throat" is an object, and is part of the notself. Seldom, except as metaphysicians, do we identify ourselves with our experience; but modern as well as ancient thought has made men recognize that for some purposes, at least, man is feeling and thinking. When we stop to recall what at some distant day we were, or if we compare what now we are to what in old age we shall be, it is thought and feeling that we summon and compare with present thought and feeling; and in this individual experience of objects rather than in any object, we recognize ourselves, past, present and future. Indeed, when convinced that our experience rightly and fully mirrors the world, we feel a self-appreciation, a kind of assurance, which has for its object, not the historical self, which might be said to have the experience, but the experience itself, with which we identify ourselves, and of which we are proud.

I cannot add to my categories what James calls the self as thinker, or knower. This is distinct from all objects known; and it is not part of the experience, but is the present, passing, inchoate, judging thought, which herds, brands, adopts and inherits the past thoughts which the thought just dead bequeaths to it. These functions are, even according to James's account, hypothetical. And according to that account, again, this ' thinker' cannot be a content of consciousness in which the individual recognizes himself, for such recognition would make it the known, not the knower. This thinker, indeed, seems rather to be, for James, the individual which is or may be self-conscious, taking the place which in psychology the 'psychophysical organism' now tends to occupy, It is, then, an ego rather than a self, if it is either.

${ }^{1}$ Principles, Vol. I., p. zor. 
With regard to each of the six categories of the self which I have here described, no one of them seems to be a subspecies or a part of another. Each with its corresponding not-self seems to me to make up a universe in which no other self has a place. The historical self, for example, is not to be found, I think, among the objects of which the experience self has knowledge, but rather comes to light only by a change of the system of thought, and the presence of another category of existence, with other kinds of self-feeling.

I realize how crude and unsatisfying my presentation is; but I hope that I may bring the attention of others to the very inadequate treatment that the 'self' now receives, particularly in reference to pride or self-appreciation. Psychology should be able to offer much more light than it does offer to aid in the correct description and evaluation of this important class of emotions.

There are some points that may occasion unnecessary misunderstanding, to which, therefore, I will briefly refer. First, I hasten to admit that within each category of self appear many sub-species of self; 'selves' that conflict or accord with each other, and 'selves' that go to build up for each individual one or other category. Within the historical self may appear both the athlete self rejoicing in applause, and the candidate self turned away by a teachers' committee. Within the will-self contend the 'aggressive' and the 'accommodating' self. Within the experience-self moods of gloom and joyous insights mingle; and so on.

The synthesis of these selves is no doubt just as important as the analysis; but of course the latter must precede. Preyer refers to the ' $I$ ' concept as the abstract conceptual unity of such selves as he mentions. ${ }^{1}$ But such a concept is not a self, I should say, not a content of individual consciousness in which the individual recognizes himself, but rather a concept of the ego, an abstraction of the content common to all egos. The ' $I$ ' for each individual seems to have merely an analogical reference to the several categories of self, and to be a functional or practical, rather than a conceptual unity. That is, I do use the term ' I' rightly for all my categories of self; but why I do, is a matter to be explained by a careful analysis of the development of the habit of so doing, rather than by an analysis of what I always and everywhere mean by 'I.' Royce and Taylor, among recent writers on metaphysics, seem to assume that the self is fundamentally homogeneous, and that essentially it is the ideal self. I cannot understand the grounds on which this position is taken.

1 The Development of the Intellect, trans., p. 205.

${ }^{2}$ Taylor's Elements of Metaphysics, pp. 342, 350 et al. 
Many difficulties arise in keeping clear the distinctions which I here attempt to establish. For example, in the experience self the sense of the body, the organic sensation, is recognized as a very important element of that self. This sense of the body, or experience of my body, is not the bodily self, it must be noted. In the bodily self I identify myself with the body, not with my experience of it. These are two very different ways of thinking.

What Baldwin calls the socius, 'the self of all the rich social relationships," ception of the relation of the self to the not-self, which may apply in different ways to the ideal self, to the historical, the will, and to the bodily self - a conception in which self and not-self stand together under a wider unity. The unity of the ideal self and not-self seems to be logical merely: that of the historical self and not-self seems to be the unity of historical action; that of the will-self seems to be the unity of attitude; and that of the bodily self, the unity of natural or mechanical law. I regret I have not space to develop this point properly.

A very interesting and, I think, elucidating application of the principles of this paper may be made to certain cases of double consciousness. In the case of Leonie B., as narrated by Sidis, in his Psychology of Suggestion, p. I3I ff., Leonie is hypnotized and assumes a different name, Leontine. In this state she, Leontine, is told to remove her apron after the hypnotic state has ceased. This she does. She is then rehypnotized, and volunteers this statement: 'How stupid the other (Leonie) looked while I took off her apron!' Unfortunately these experiments are not so described that we are helped to understand the content of the subject's mind. The hands and arms with which Leontine took off Leonie's apron were the hands and arms under which that apron was tied! Leontine must so have thought of herself that one aspect of those hands and arms were knit up with herself, while another aspect was not so knit up. If Leontine thought of herself in terms of the bodily and will-self, to the exclusion of the historical self, one can see how the sense of touch and movement of hands and arms were recognized as parts of self, while the sight of herself was to her like another person. The old soldier, Father Lambert, who regarded his body as a machine, 'it,' not himself, ${ }^{2}$ insisting that he himself had died at Austerlitz, apparently owing to the insensibility of his skin, had lost the natural, im-

'Social and Ethical Interpretations, p. 41.

${ }^{2}$ Stout, Manual, p. 53r. 
mediate connecting link between his visible and his kinæsthetic perception, which must be the usual means through which, to the visual and tactile image, which is one feature of the historical self, we associate the essential sense of its activity. To his enfeebled intellect, again, that insensibility would prevent the usual functional or practical identificatlon of the will-self, bodily self and historical self in the one 'I.' Hence he possessed an 'I,' in the form of the will and the bodily self, and doubtless, also, an image of the historical self lost since Austerlitz, associated with that 'I.' But he was incapable of associating any element of that ' $I$ ' with the perceptions which normally should now constitute in part the historical self. Even if this explanation is incorrect it seems that such cases confirm the general position that the self is homogenous, but that there is only an analogical relation between the several categories of self.'

Percy Hughes.

UNTUERSTTY OF MINNESOTA.

1 The MS. of this article was received June 27, Ig06.-ED. 